\title{
Management Strategies for Global Businesses
}

\section{$2.1 \quad$ Introduction}

This chapter examines management strategy theories for global businesses. What extent of company's resources should be assigned to overseas operations, and what minimum percentage of revenues should come from overseas operations? Should investments be made in regions such as China or Southeast Asia with existing substantial business establishments, or should expansions into new markets such as India, the Middle East, and Africa be considered? Which corporate functions should be transferred overseas? This chapter attempts to understand the theoretical aspects of decision-making in the allocation of management resources within global businesses.

We first present an overview of corporate management strategy theory as a premise to understand global strategy. The objective of management strategy is to effectively utilize corporate management resources, such as personnel and technology, in accordance with external environmental factors such as competition and customer needs. In that process, there is a resource-based management theory that emphasizes on internal factors to create strategies that make use of the strengths of a company's internal resources. In addition, there is a positioning theory that emphasizes on external factors such as the selection of areas that are deemed suitable to acquire mid- and long-term profits through a company's external environment analysis. These approaches are introduced herein, although in reality, a company's internal factors and external environment influence each other, and change over time. Therefore, these two approaches must be considered together when setting a specific management strategy.

With that in mind, we then examine global management strategies - those that acknowledge national borders. It is critical to understand the differences between environments across key business destinations and domestic business environments. Advancements in telecommunications technology such as the internet, lower transportation costs, and elimination of trade barriers due to the initiatives of 
international organizations such as WTO, are factors that have contributed to a flatter world. However, as noted previously, national border barriers still exist, and are particularly evident in developing nations such as China and India. Global businesses must understand differences in business environment that are significantly different from their home countries, and overcome them or use local environments to their benefit to capture attractive markets that exist on the other side of these barriers, as is the case with offshore software development. With that in mind, we review strategy designing theories. Finally, we examine corporate management strategy in case of global expansion. Specifically, we focus on the headquarters' level of control in overseas operations. Corporate activities integrated on a global level require a certain level of control of overseas entities. However, the presence of national barriers indicates that there are management methods appropriate to business environments in which overseas entities operate. Thus, it is often more effective to delegate everyday operations to local entities. This chapter minutely analyzes the balance between headquarter control and local autonomy. Japanese corporations exert a stronger level of headquarters' control compared with their western counterparts. In addition to international comparisons, I-R grid framework and current state of affairs are examined.

\subsection{Concepts of Corporate Management Strategy Theory}

\subsubsection{Scope of Management Strategy}

Adopting management strategies within companies increases corporate value. Corporate activities result in economic profit to company stakeholders, such as shareholders, employees, and important partners. Corporate strategy aims at mid- to long-term courses of action that maximizes the corporate value provided to stakeholders. For publicly traded companies, improvement in market capitalization will ultimately benefit the company's stakeholders. Corporate performance is often analyzed in terms of profitability ratios. However, a temporary improvement in profitability ratios may sometimes hamper future profit. For example, companies sometimes reduce the level of their investments that would otherwise positively impact future business performance, such as R\&D activities. Even though this may temporarily improve profit, a measure with no prospects of improving the long-term growth of a company will not increase its market capitalization, and therefore is not an appropriate management strategy. "Mid- to long-term" is part of the corporate strategy definition is because it accounts for the integration of corporate activities over an extended time period.

We examine corporate strategy in more detail. Policies regarding management methodologies and mid- and long-term corporate direction are classified into four levels of abstraction: mission, objectives, strategies, and tactics (MOST).

The most abstract among them is "mission," or the fundamental principles or vision of the company. The mission succinctly expresses the essence of the company. For example, Morita Akio, Sony's former Chairman, identified Sony's 
mission as being "a pioneer." This mission encapsulates the management's direction that has provided the world with technologically advanced products, such as the transistor radio, Trinitron television, and Walkman. Sony believes in being a leader and does not follow other companies; its management policy has always maintained the challenge of pioneering new products.

"Objectives," refer to specific objectives relating to the mission. Objectives are given a specific timeframe under which they need to be achieved. Large companies announce their 3-5-year management strategies called "mid-term management plans." The objectives outlined in these plans may be, for example, to increase overseas revenues to more than $50 \%$ of total revenues within 3 years by strengthening global businesses.

"Strategies" refer to a company's plan to achieve the objectives, and its contents detail its mid-term management plans. These strategies significantly impact overall company management, such as new product development for the Chinese market to increase overseas revenues to greater than $50 \%$ of total revenues or the acquisition of local companies to expand local distribution channels.

"Tactics" refer to the plan to execute strategies. The creation and execution of specific plans are often left to the discretion of divisions. Expansion of local channels may be implemented by the marketing division, while new product development may be implemented by the development division. Thus, management meetings comprising the company president and division leaders typically discuss issues at a strategic level, and later share them with the rest of the company. Among Japanese corporations, global strategy is an increasingly important management strategy because overseas markets contribute to the increasing share of overall corporate revenues.

\subsubsection{The Three Cs and SWOT Analysis in Management Strategy}

The term "strategy" in the concept of "management strategy" was originally a military term, with Japanese characters derived from the ancient Chinese classic "The Art of War" by Sun-Tzu. A famous phrase from that work states that "if one knows one's enemies and knows oneself, one will not be imperiled in a hundred battles." When comparing it to management strategy, "oneself" might refer to corporate strengths and weaknesses, while "one's enemies" might refer to competitors. Value is created from corporate activities when customers purchase products or services of a company. Thus, customer awareness is also important. Therefore, designing management strategies begins with the analysis of the three Cs which are "company," "competitors," and "customers."

SWOT analysis is a commonly used tool in the determination of corporate strategy. SWOT refers to "strengths, weaknesses, opportunities, and threats." Strengths and weaknesses refer to internal management resources and correspond to the aforementioned "know oneself." Therefore, it is important that the management identifies corporate strengths and weaknesses, and develops necessary strategies that take advantage of strengths and avoid weaknesses. On the other hand, 
Fig. 2.1 SWOT analysis

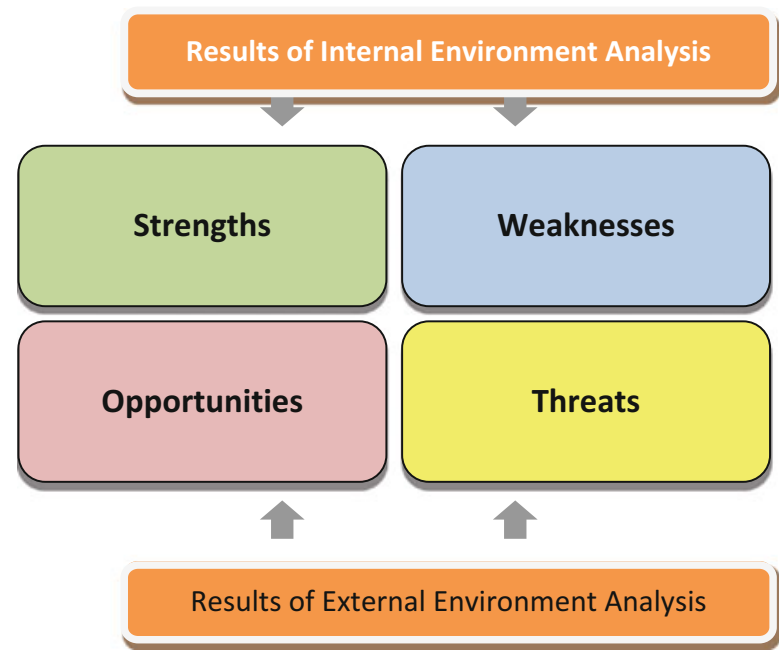

opportunities and threats are external to a company. Opportunities refer to a company's business opportunities, for example, entering an overseas market to find new customers. Threats, on the other hand, refer to powerful competitors or the expectation of heightened competition in the company's business sphere because of deregulation. Management strategies set by companies should avoid areas with large threats and focus on areas with greater opportunities (Fig. 2.1).

Determining management strategies requires a combination of both internal (strengths and weaknesses) and external (opportunities and threats) factors. There are two theories regarding the areas where more emphasis should be placed. The first is "Porter's Positioning Theory" that emphasizes external factors. Porter's theory of management strategy analyzes the forces that result in lower profitability using the "Five Force" model (Porter 1980). The five forces are outlined below:

1. Bargaining power of customers

2. Bargaining power of suppliers

3. Threat of new entrants

4. Threat of substitute products

5. Competitive rivalry within an industry

Under SWOT analysis, these factors focus on "threats" and suggest that management resources should be channeled toward areas where threats are relatively small.

On the other hand, the theory that emphasizes management resources in terms of corporate strengths (the " $\mathrm{S}$ " in SWOT) is called the "resource-based management strategy theory" (Barney 1986, 1991). Sustained competitiveness is dependent on having management resources (technology, organizations, personnel, supplier networks, etc.) that are rare and difficult to copy. This theory states that management strategy should be directed toward taking advantage of such strengths. The VRIO framework is used by this theory; we discuss this framework below. 
Value: Is the company's technology far superior to that of its competitors? Does the company have better human resources than its competitors? Does the company have a network of powerful customers? Are the company's assets of high value? Rarity: Are the company's assets rare compared with those of its competitors?

Imitability: How difficult is it for competitors to imitate the company's technology, and can "rarity" be maintained for a certain length of time?

Organization: Does the company have an organizational structure that can effectively utilize available management resources?

Management resources that can affirmatively answer the above questions can bring about sustained competitiveness; therefore, management strategies that can maximize the utility of such resources must be undertaken. Moreover, because the types of management resources provide an economic value change according to the environment in which a company is placed, there is an expanded theory called the "dynamic capability theory" that emphasizes the rearrangement of management resources in a dynamic fashion (Teece et al. 1997).

Needless to say, these two theories of management strategy are not in conflict with each other, and must be used in conjunction when designing corporate strategies to maximize the value of a company's internal management resources in response to external environments. Management strategies in Japanese corporations are generally based on a resource-based management theory that emphasizes internal environments (Numagami 2009). Japanese corporate management is built on a long-term employment system based on stable relations. In addition, there is a strong tendency to build stable relationships with the network of suppliers and customers. Thus, resources such as technologies, personnel, and relationships with customers tend to be built over time, with corporate strategy designed around such management resources. Alternatively, the US and other Anglo-Saxon-based countries have well-developed external labor markets with highly fluid employment. In addition, dynamic changes in company structure due to M\&A activities force companies to analyze external business environments and make a prudent realignment of management resources when attractive markets are found. Thus, Porter's positioning theory is more applicable.

However, as companies are becoming more global, the methods in which management strategies were designed in the past to respond to varying market transactions and country-specific systems are beginning to break down. Many Japanese companies in a global business environment struggle because of a non-functioning Japanese-style management structure. For example, in its overseas subsidiaries, business models based on stable and long-term labor relationships and long-term customer and supplier relationships often do not work. There are exceptions to this, such as in the automotive industry where companies have launched a Japanese-style supply chain system overseas to great success. However, these cases are exceptions and creating management strategies requires a shift in thinking. Specifically, companies must strengthen their analysis of external environments, where they have not made much effort domestically in the past, and speed up changes in business domains using M\&As or other entry methods. 


\subsubsection{Global Strategies and Differences in Internal and External Business Environments}

To adopt a global strategy as part of a corporation's management strategy, it is first necessary to analyze the differences in internal and external business environments. In doing so, we must be cognizant of countries and regions that are important to the global strategy. This is particularly important when considering business in countries such as China and India that have significantly different business environments from those in developed nations. In reality, some countries already have production centers and must be examined from the perspective of existing overseas networks. Moreover, in the case of parts manufacturers, it may be necessary to examine entry into specific countries because of key customer demands. In our discussion, we assume that the important countries have already been decided upon when contemplating a global strategy.

First, we must understand the differences in business environments that exist between the domestic market and the countries in question. National barriers exist even in a "flattened world"; therefore, we must first grasp the significance and types of barriers, and move on to examine the strategies to overcome them. In proposing the CAGE framework to explain the differences in domestic and foreign business environments, Ghemawat states four kinds of distances between a home and a foreign country (Ghemawat 2007). We explain the CAGE framework as follows:

Cultural distance: differences in language, customs, religion, etc.

Administrative distance: differences in foreign investment policy, regional economic blocs (the existence or absence of free trade agreements), political proximity, currency, lack of colonial ties, etc.

Geographic distance: differences in transportation costs and times, time zones, etc. Economic distance: differences in income levels and wages, transparency in commerce practices, characteristics of corporate systems, etc.

Each of these principles is explained with specific examples. We use Ghemawat's examples that examine the distance between China and India from the perspective of a US corporation (Table 2.1).

Low language barriers make India very attractive (short cultural distance). India was formerly a British colony, and English is widely spoken, this is not so in the case of China. In addition, a significant portion of India's elite are westernized, and have been to the UK and more recently to the US for further education. The founder of the CAGE framework, Ghemawat, is of Indian origin; he was employed at the Harvard Business School which also has several Indian professors. Moreover, there exist strong US-India elite class connections. On the other hand, China's cultural attractiveness lies in its homogenous language and people; moreover, there are many Chinese-Americans. In contrast, language and customs vary greatly in India by region, making it difficult to take a one-size-fits-all approach across the Indian region in terms of expanding business operations there. 
Table 2.1 CAGE analysis: favorable conditions of China and India for US firms

\begin{tabular}{|c|c|c|c|c|}
\hline & Cultural aspects & Administrative aspects & $\begin{array}{l}\text { Geographical } \\
\text { aspects }\end{array}$ & Economy aspects \\
\hline \multirow[t]{4}{*}{ India } & \multirow[t]{4}{*}{$\begin{array}{l}\text { English-speaking, } \\
\text { westernized elite }\end{array}$} & $\begin{array}{l}\text { Common ruler } \\
\text { (from the colonial era) }\end{array}$ & & Specialized labor \\
\hline & & Legal customs & & High profitability \\
\hline & & Political familiarity & & \multirow{2}{*}{$\begin{array}{l}\text { Westernized } \\
\text { business customs }\end{array}$} \\
\hline & & Low political risk & & \\
\hline \multirow[t]{3}{*}{ China } & $\begin{array}{l}\text { Standardized } \\
\text { language }\end{array}$ & Ease of doing business & $\begin{array}{l}\text { Proximity to } \\
\text { west coast of US }\end{array}$ & Large market \\
\hline & \multirow[t]{2}{*}{$\begin{array}{l}\text { Chinese- } \\
\text { Americans }\end{array}$} & \multirow[t]{2}{*}{ Economic zones } & $\begin{array}{l}\text { Ports and road } \\
\text { infrastructure }\end{array}$ & $\begin{array}{l}\text { Access to abundant } \\
\text { labor and capital }\end{array}$ \\
\hline & & & $\begin{array}{l}\text { East Asian } \\
\text { manufacturing } \\
\text { network }\end{array}$ & $\begin{array}{l}\text { Supply chain } \\
\text { network of foreign } \\
\text { firms }\end{array}$ \\
\hline
\end{tabular}

Source: Compiled from Ghemawat (2007), Table 2.2 (p. 46)

In terms of administrative distance, India and the US have similar legal systems, as the economic systems were built by a common colonizer-the UK. Moreover, India's political system is said to be somewhat pro-American. Conversely, relations between China and the US have been somewhat strained in the past. From the Indian perspective, a further attraction is the "low long-term risk" that the country poses, although some may argue that point. An Indian characteristic is its entrenched democratic political system, which contrasts with the one-party rule of communist China. India follows a democratic political process to bring about major policy changes, while China most likely does so through a top-down approach. Therefore, in China, companies must always conduct business with an awareness of this inherent political risk.

Alternatively, the ease with which businesses can be created is a major attraction of China. In addition, it also provides incentives to foreign investments, such as the economic zones. China is said to be a country not of the "rule of law" but of the "rule of men," thereby making the dealing of several business procedures simple and at the discretion of civil servants. India, however, has several business regulations, which need to be adhered to strictly. For such purposes, conducting business operations in China is certainly more attractive. In addition, economic zones in China were first created in the 1980s, and this program has been a success, with many zones existing today, particularly along the coast. However, recently the Chinese government imposed stringent regulations toward foreign firms that build simple production centers within its borders; India has taken cues from China's model of economic zones and has implemented a similar program.

In terms of geographical attractiveness, compared with India, China is relatively closer to the west coast of the US, and has the necessary infrastructure-support, such as harbors, in place. This deems China as more attractive than India. In assessing 
these regions as manufacturing centers, geographical proximity is an important factor. Southeast Asia has well-developed infrastructure and a production network of component and product manufacturers that extend beyond national borders. Vietnam, Laos, and Myanmar neighbor China, and are connected via expressways. For example, the Pearl River Delta area of Shenzhen and Guangzhou has manufacturing agglomerations in electronics and textiles. Moreover, travel routes are available from these areas to Bangkok via continental expressways. While India's major cities are situated along the coast, the traffic network between the major cities remains incomplete because of the central mountain region, thus hindering the creation of manufacturing centers.

In terms of economic attractiveness, India has many engineers in software and other fields. In addition, the market is not as competitive as China, making profitability relatively higher for companies doing business there. Furthermore, managements in India are familiar with the Western style of business, perhaps because of westernization of the elite class. Conversely, China's corporate system is built on nationalized companies, and corporate governance is often not transparent. As illustrated, India has superior soft-business infrastructure, while China has a large market with high wage levels. Moreover, the Chinese labor force is far superior to that of India and has more capital. Another benefit of conducting business operations in China is the relatively greater number of foreign firms in the domestic supply chain system and in other business activities, thereby making it easier to form local partnerships.

\subsubsection{Is China a Market or a Factory?}

From the perspective of US companies, India and China are both distant and close within the CAGE framework. Given that, the question lies in how companies should globally expand based on the differences in domestic and foreign business environments? Before introducing theories of global strategy, we first examine whether China should be perceived as a market or a factory.

There are variations in the types of global businesses operating in China depending on whether they perceive it as a market or a factory. Figure 2.2 classifies these businesses in four ways, with its "advantage in production" axis, in which companies view production in China as "being more advantageous than production in Japan," and the "market advantage" axis, in which companies view China as having "a more attractive market than that of Japan." One major "distance" critical in this case is the difference in income levels between Japan and China. China's total GDP approximates that of Japan. However, China's population is ten times that of Japan. Thus, the per capita GDP of China is less than one-tenth of that of Japan. Of course, China is a vast country with wide regional disparities. Many Chinese natives along coastal regions of Beijing and Shanghai have income levels higher than the Japanese. However, the country as a whole has low labor costs and its consumers prefer lowpriced items, which is different from the case in Japan. 


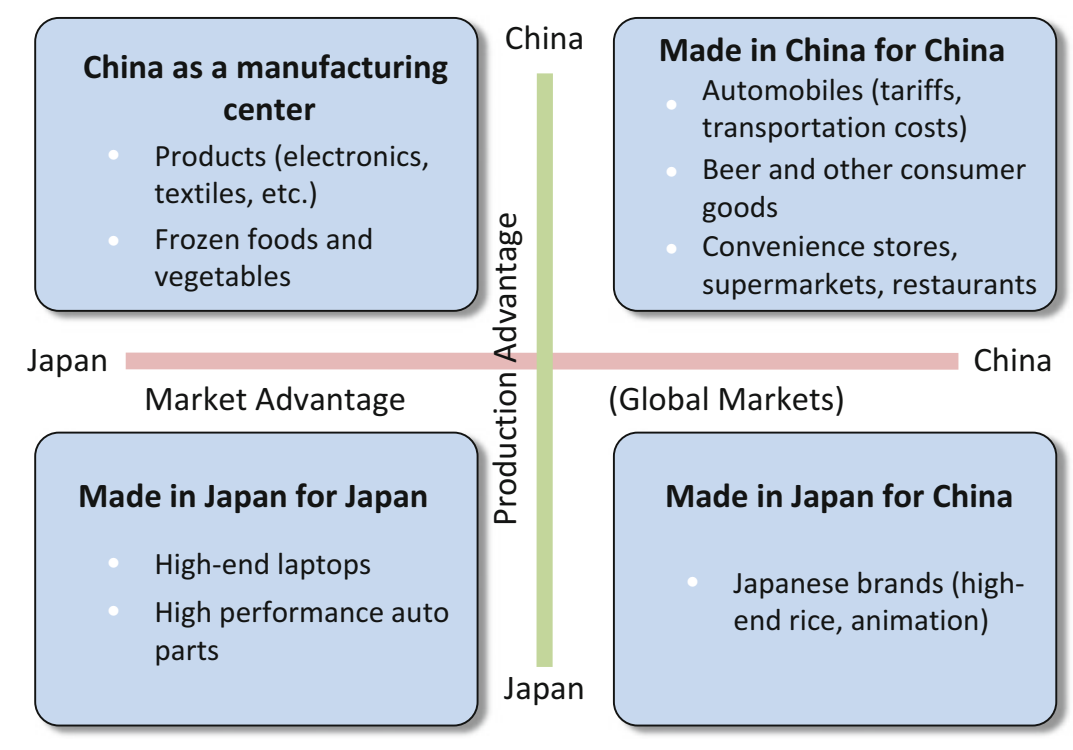

Fig. 2.2 Is China a market or a factory?

The top-right corner depicts the so-called "locally-produced, locally consumed" consumer products, produced in China for domestic consumption, such as vehicles and beer. High tariffs on vehicles in China and high transportation costs make local production more feasible. China's auto market is second only to the US and is growing annually, giving rise to manufacturing of vehicles primarily for domestic use. The percentage of transportation costs to the overall production costs for products such as beer are relatively high, rendering such consumer durables to be "locallyproduced, locally-consumed." With China's entry into the WTO, foreign capital regulations in the distribution industry have been reduced, resulting in an increase in the expansion of retail stores such as convenience stores and supermarkets.

The lower-right corner applies to products that are manufactured in China and exported to the rest of the world, according to the "China as a factory" model, and applies to almost every known product. In particular, electronics and textiles are manufactured in the agglomerations at the Pearl River Delta area called "the factories of the world." These products are exported throughout the world. In addition, with Japanese food product manufacturers recently making forays overseas, there has been significant development in frozen foods and vegetable production in China for the Japanese market.

Among other costs, China's low labor and land costs, present a production advantage for many products. On the other hand, products that must be manufactured in Japan are limited to those requiring a high level of manufacturing technology. For example, high-end electronics such as ultra-slim laptops are manufactured in Japan. In addition, vehicles are manufactured in Chinese factories; however, 
high-performance automotive parts are often manufactured in Japan and then exported. These products are universal parts supplied throughout the world being manufactured specifically for the Chinese market. Finally, there are only few product categories that are manufactured in Japan exclusively for the Chinese market. Perhaps Japanese animation films or high quality rice, sold as Japanese brands, can be placed in such a category.

The objective of management strategy from the perspective of globalization is the maximization of corporate value (i.e., long-term profitability). There are two ways to increase profitability: increase revenues or reduce costs. Our exercise of questioning China as a market or a factory effectively asks whether a company should elect to increase revenues (the market) or reduce costs (the factory) in its approach to conduct global business operations in China. A conclusion is arrived at by considering the distance in business environments between Japan and China. Generally, when viewing China as a market, the smaller the differences the better, as it becomes relatively easier to manufacture domestic Japanese products specifically for the Chinese market. On the other hand, when viewing China as a factory, differences will be exploited; thus, the larger the differences the better.

This exercise considers how to conduct business operations in China with existing products and services; it is not meant to provide answers to the strategic question of how to foster mid- and long-term growth in developing nations such as China and India. We have already discussed case studies on Japanese corporations entering China as they are easy to understand. However, in case of India, there are very few Japanese products that can be sold in India as-is. Because of the high cost of Japanese consumer electronic products, Japanese companies lag behind Korean companies such as Samsung and LG. While the potential market for beverages and food products is large, food culture and customs are very different in India, making it difficult to expand the market for Japanese foods there. Specific local circumstances must be taken into consideration while developing products and services for local markets.

In addition to the CAGE framework and its distances in terms of global businesses, Ghemawat also proposes a three-axis "AAA" framework for global strategies, that comprises "aggregation," as provided by domestic production; "adaptation," or the localization of products for local markets; and "arbitrage," which leverages distance. Figure 2.3 illustrates this framework. The horizontal axis balances adaptation and aggregation. Adaptation refers to the localization of products and services provided to a domestic market that reflects the needs of that market. Aggregation refers to providing standardized global products for common needs in varying overseas markets. Both adaptation and aggregation are parameters determined by global market characteristics; as the level of adaptation increases, a product will be more accepted by local markets, but will result in an increase in development costs, consequently, nullifying economies of scale for global markets. Companies must find the ideal balance in terms of national and regional market differences as well as in the size of local markets.

"Arbitrage" is presented as the vertical axis. Adaptation and aggregation form the dimension that determines the extent to which distances in global businesses can be diminished, while "arbitrage" derives the value out of these distances. Typical 


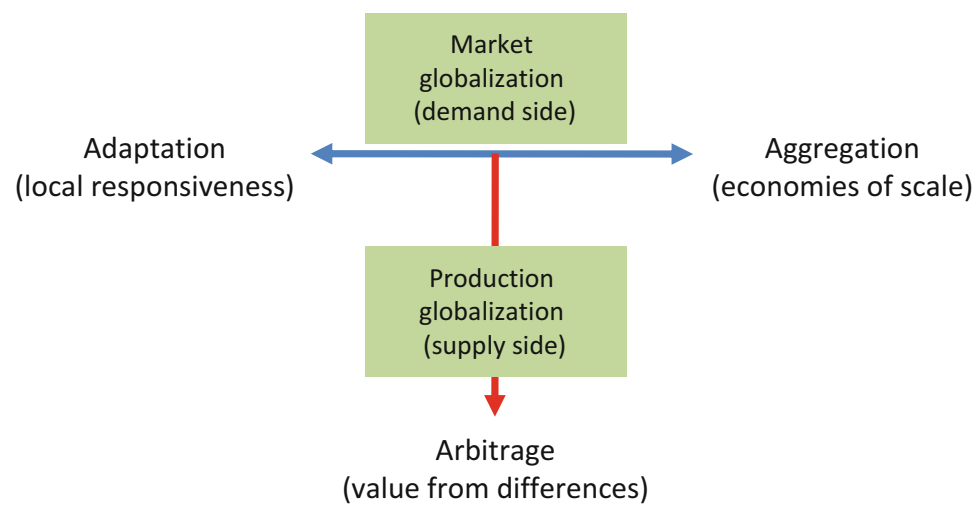

Fig. 2.3 AAA framework

arbitrage strategy within global businesses can be seen in local production that exploits wage differences. India's offshore software development, depicted in the "The World Is Flat" (Friedman 2005) is a good example of this. Many Japanese manufacturers have adopted this arbitrage position and have established production centers in China. Arbitrage is a widely used term in the finance industry, and arbitrage trades refer to those trades that generate profit by exploiting differences in interest rates within financial markets. Financial products are quickly traded in the market even in case of a minute arbitrage opportunity; such actions in turn resolve market distortions. Arbitrage opportunities are likely in a global business environment with national barriers. China has become popularly known as the world's factory, and companies world over are investing in China, in the hope of taking advantage of arbitrage trading opportunities. For the same reason, western companies have concentrated offshore development in India.

We now return to examine the AAA framework by using the consumer electronics industry as an example. Consumer electronic products can be divided into whitegoods products, such as washers and refrigerators, and audio/visual (AV) equipment, such as televisions and video cameras. Generally, overseas expansion can be executed efficiently for white-goods products in terms of "adaptation" and for AV equipment in terms of "aggregation." Sale of white-goods products is closely associated with country-specific lifestyles. For example, most washers in Europe are front-loading and have a vertically rotating drum; this design consumes relatively less electricity and water. Europe has a much stronger propensity to environmental awareness and has stringent energy conservation policy standards. On the other hand, washers in Japan and the US are typically top loading and spin horizontally; this design consumes relatively more water. Similarly, the capacity of refrigerators varies according to shopping frequency. In the US, consumers often buy goods in bulk because they can load them into their cars; this type of shopping requires relatively large refrigerators. Therefore, white-goods products must be localized for each market by observing how locals live. In lifestyle research centers located in developing nations such as China, Panasonic analyzes home environments and lifestyles of local consumers by visiting their homes. Product development is, 
therefore, based on information obtained in these lifestyle research centers so that products can be adapted to local market environments.

On the other hand, AV products such as televisions and video cameras are not impacted greatly by lifestyle differences. Of course, there are always differences such as in television's broadcast systems and frequencies, but the basic functions are universal. Selling these products in developing nations requires an "aggregation" strategy to reduce costs and increase cost competitiveness. The price of AV products drops annually. Manufacturers in China and other developing nations are technologically catching up with Japanese manufacturers, and while Japan may have higher quality products, their acceptance rate in many markets will be difficult without price reductions. Sony has standardized the design of components that are not specific to any particular region, such as digital video processing chips, to increase television development efficiency. In doing so, Sony has centralized development teams in Tokyo. In addition, Sony has strategized to distance itself from low price competition in developing nations by improving their brand image through their specialty shops, called "Sony Style."

How is arbitrage used to the advantage of Panasonic and Sony? Both companies have production centers in low-cost regions such as China, and benefit from the merits of arbitrage through cost differences. Moreover, they are in the process of shifting product development and design to developing countries such as China and India; however, teams located in Japan still play a central role in these functions. As indicated in Fig. 2.4, companies must choose between adaptation and aggregation; however, it is noteworthy that arbitrage can be accomplished in combination with either.

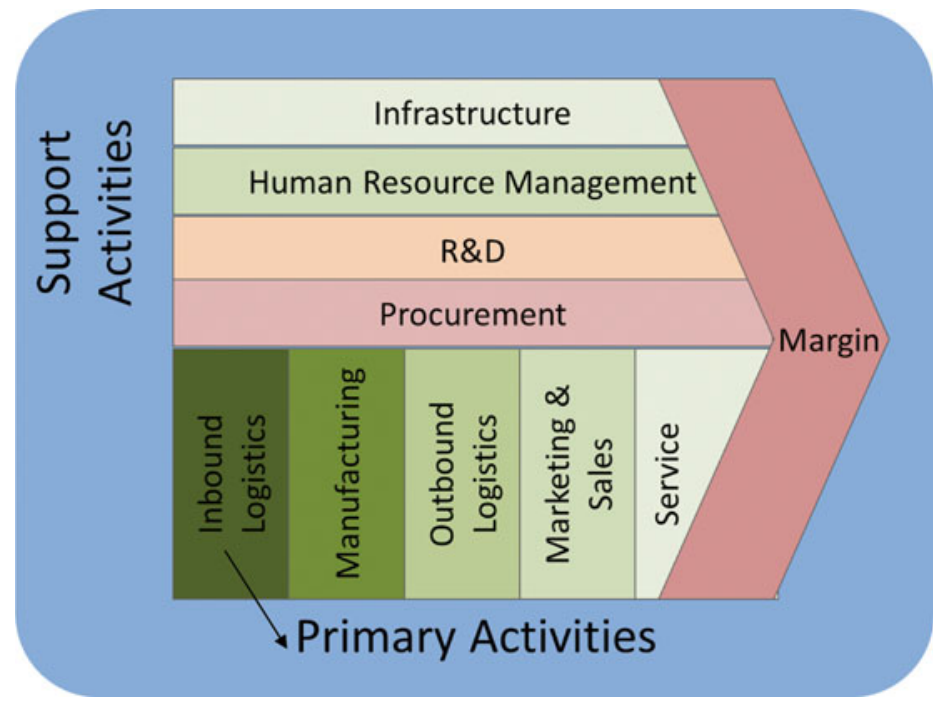

Fig. 2.4 Porter's value chain. The integration of procurement and logistics, procurement, and logistics (Source: Porter 1980) 


\subsubsection{Value Chains and Global Strategy}

The AAA framework suggests ways to manage distances that have been recognized in the CAGE framework within international business expansion. This is effective when considering global business strategy, though this discussion remains highly abstract. The application of this framework to a more detailed corporate strategy requires further examination of corporate activities. We separate what we call "international business expansions" into components of corporate activities, and then consider how each activity contributes to an improvement in corporate value through globalization. The concept of value chains as proposed by Michael Porter breaks down a company's internal functions and combines the value added by each function, leading to overall corporate value.

Figure 2.4 indicates manufacturers such as automakers. The automobile manufacturing process begins with the procurement of parts. These parts are assembled into completed vehicles at factories, exported, and then sold to consumers via dealer networks, who provide post-sales services such as maintenance services. The entire process from vehicle production to post-sales service, through activities such as production and sales, are called primary value chain activities. However, the valueadded activities for the company as a whole are not limited to such activities, and corporate functions exist to support divisions that provide these primary activities, such as divisions responsible for personnel management (human resources), R\&D, and procurement.

Companies are organized along these functional divisions, with leaders of each function comprising the management team. These leaders are often directors and corporate officers. A clearer image of global strategy appears when each business unit considers increasing the value chain of activities in global expansion. The AAA framework becomes more crystallized when deliberated at the business unit level.

Figure 2.5 indicates in basic terms, the three $R \& D$ areas, procurement and manufacturing, and sales and service as they apply to overseas expansions. First, for $\mathrm{R} \& \mathrm{D}$, particularly research, it is vital to aggressively incorporate advanced technology from overseas markets. A typical example of this is the establishment of research centers in Silicon Valley or near Boston, and the conducting of joint research with local universities and research institutions. Developing products in response to local needs is also critical. As earlier stated, "adaptation" is critical for white-goods products, but it is executed only when differences in lifestyles are of significant distance in term of the CAGE framework, the local market is of sufficient size, and economic rationale for developing products with localized specifications is high. In addition, offshore development in regions such as China is a form of R\&D "arbitrage." Typically, outsourcing often refers to the offshore development performed by software companies; however, it may also imply internationalization of activities such as product development and design.

Next we look at procurement and manufacturing activities, which essentially utilize "aggregation," or the expansion of production facilities from the domestic country (mother factories) to the overseas market. In this case, cost margins are possible by arbitrage of wage differences and in the use of local suppliers. A key 


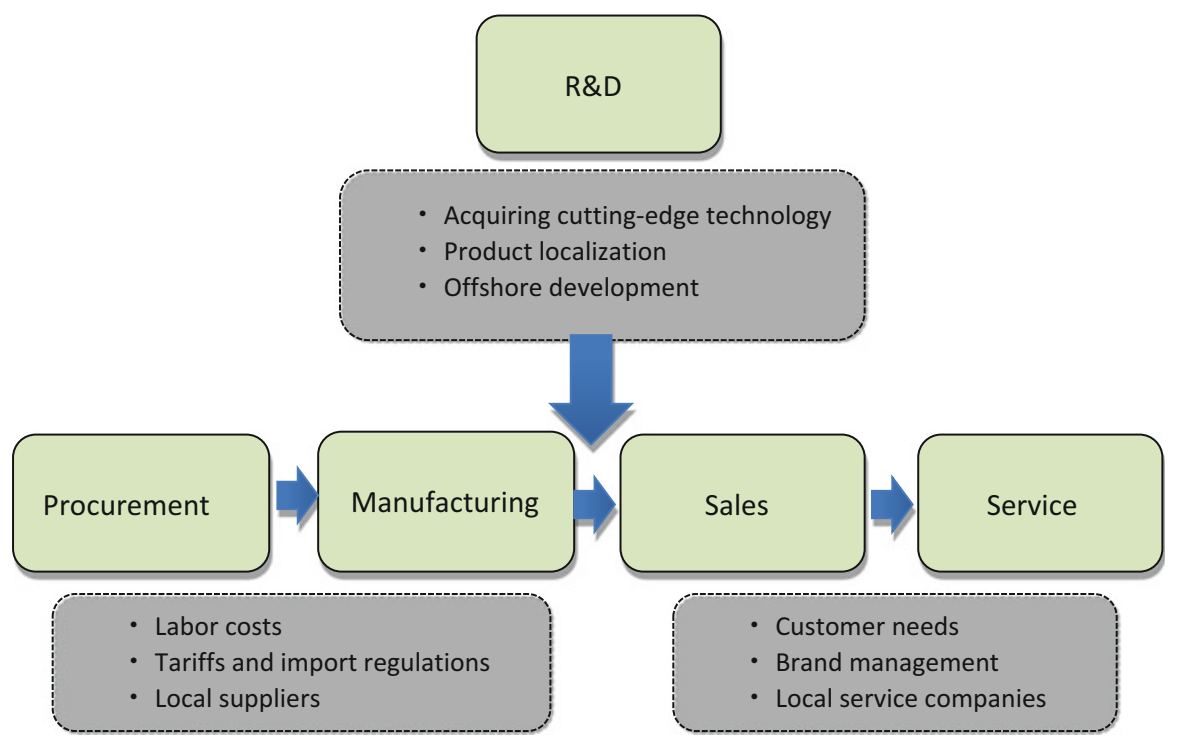

Fig. 2.5 Activities of overseas entities by corporate function

limitation to creating overseas production facilities is the risk associated with such high investments. In addition, there are significant transaction costs associated with managing local labor and with decentralization of production facilities. Balancing both determines the financial feasibility of localization. Generally, developing nations have higher tariff rates than developed nations, so that local production makes more economic sense as compared to exporting products to these countries. However, the recent entry of many developing nations into the WTO has resulted in a declining average tariff rate. In addition, regionally flat economic zones, such as those created by the ASEAN Free Trade Agreement, an economic partnership agreement for ASEAN countries, are beginning to take shape. This is in turn causing the production centers of Japanese corporations, which were formally spread throughout Asia, to be concentrated in single countries. Recently, ASEAN entered into economic partnership agreements with Japan, India, and China, and integration of production centers within Asia is expected to continue further.

Finally, we look at sales and service as critical toward understanding the needs of local customers, and as the function most essential for successful localization. Expanding product sales and services in each region requires activities rooted in that region, as well as the cooperation of local companies in networks such as distribution and retail. Thus, there is a strong tendency toward "adaptation" within the AAA framework, with a high level of "arbitrage" from the perspective of highly utilized local sales staff. On the other hand, in cases where brand management is important, as is the case with cosmetics, companies must take care to balance aggregation and adaptation. For example, when Shiseido entered the Chinese market, it used both the SHISEIDO global brand and the "Aupres" brand that was created 
specifically for the Chinese market. Separating the brands circumvented the possible damage that could be caused to its global brand while maintaining its ability to go after a large local customer segment (the volume zone) (refer to Chap. 9 for details).

\subsection{Relationship Between Headquarters and Local Entities}

So far we have examined global business strategy from the perspective of corporate activities. We continue our discussion by focusing on organizational aspects. Corporations establish local subsidiaries in various countries, and delegate operations to them as a means of actively pursuing businesses on a global scale. An important issue to consider is the extent to which headquarters should control these local entities.

To examine this issue, we present the I-R (integration responsiveness) grid shown in Fig. 2.6. Integration implies a strong central organizational structure with high control by the headquarters (i.e., global integration), while responsiveness implies a decentralized organizational structure with highly autonomous local entities (i.e., local responsiveness). The I-R grid was created by international business academics, Prahalad and Doz (1987); this framework has been used extensively in the field of international business.

Ghemawat's AAA framework is closely tied to the I-R grid, in which aggregation corresponds to type I, in which firms are controlled by the headquarters (global integration), while adaptation corresponds to type $\mathrm{R}$, in which voluntary responses of local subsidiaries are welcomed (local responsiveness). For example, consumer electronics can be largely classified into two major groups: AV equipment such as televisions, and white-goods products such as washers and refrigerators. As previously mentioned, the former group has standard functions independent of country or region, enabling companies to provide universally standardized products

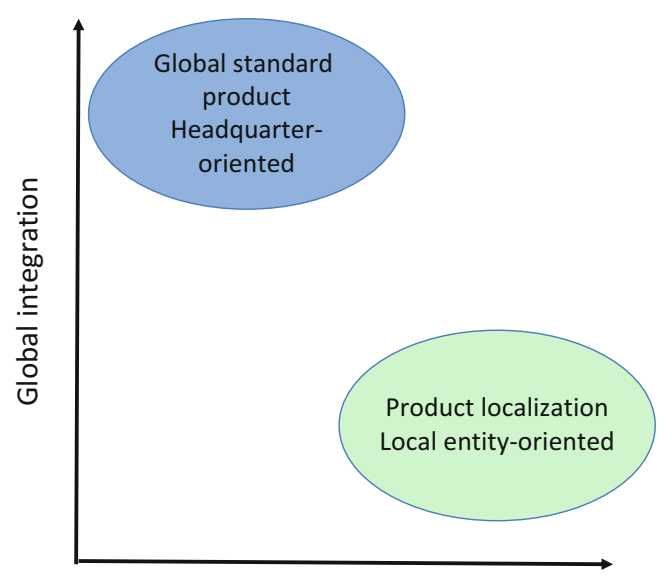

Local responsiveness 
(via aggregation), while the latter group is intimately tied to local lifestyles and must be localized according to market needs (via adaptation). The former has a type I organizational structure, while the latter has a type R one. Arbitrage, the final "A" of the AAA framework, takes advantage of the differences between the domestic country and local markets. Overseas production leveraging wage differences takes a type I structure, with the home country playing a central role, while product development that uses local ideas takes a type $\mathrm{R}$ structure.

Bartlett and Ghoshal used the I-R grid to make a comparative analysis of 30 global corporations in Japan, the US, and Europe, and examine them by industry and country (Bartlett and Ghoshal 1989). The results of this comparison showed certain industry characteristics, similar to the differences in types of consumer electronics, but more importantly, showed differences in positions within the I-R grid between countries. The locations of every Japanese, US, and European company are shown in the I-R grid (Fig. 2.7), with organizational structures of these companies classified as global, international, or multi-national. "Global" companies refer to those companies with a high level of global integration, with headquarters taking the lead and operations being uniform throughout the world. Japanese companies typically fit this pattern. On the other hand, "multi-national" companies have local entities with a high degree of autonomy and an overall corporate organization formed by groups of companies from multiple countries. Many European companies fit this pattern. "International" companies are somewhere in between, and many US companies fit this pattern.

Many of Japan's global corporations flourished along with high post-war economic growth. The Japanese domestic market grew alongside the growth in income levels, and durable goods such as consumer electronics and automobiles became

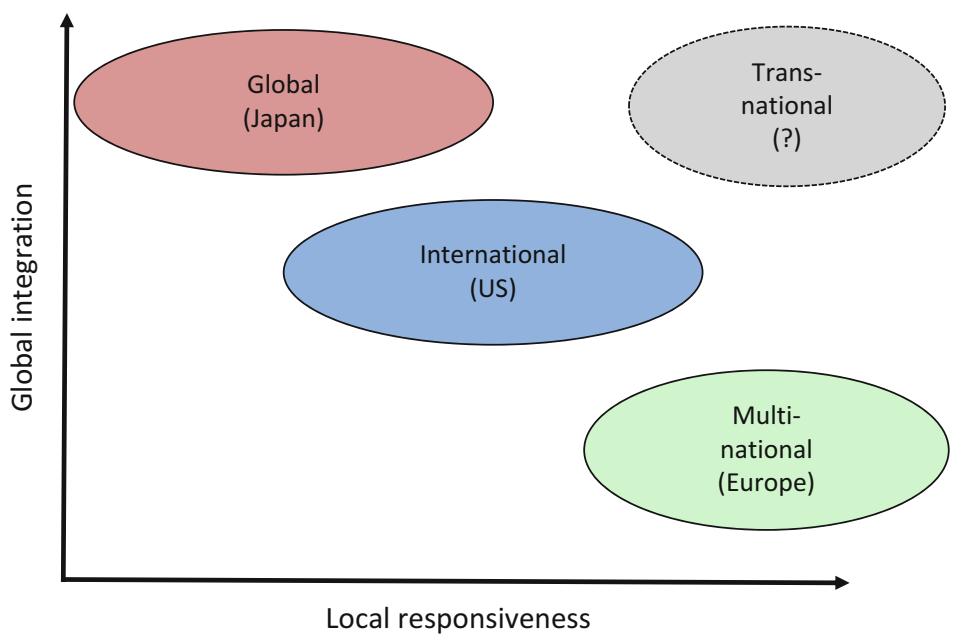

Fig. 2.7 Comparison of corporations in Japan, the US, and Europe in I-R grid 
common. Companies became competitive with import substitutions under the control of foreign companies, followed by growing corporate internationalization with a stronger export mindset. In doing so, companies entered the overseas markets by exporting global products to Europe and the US. In addition, personnel management structures in Japanese companies are based on long-term, stable relationships, with the tendency to emphasize implicit knowledge such as culture and context. Accordingly, even while globally active, local entities were controlled by what were mere extensions of management structures in Japan.

On the other hand, Europe is an amalgamation of countries, each with its own language and lifestyles. Individually, each country is smaller than Japan, but Europe as a whole is a market several times the size of Japan. Having a single currency, economic equality among European nations has increased with the liberalization of the flow of people and goods within the region. However, culture-specific differences exist among these nations and a multi-national approach becomes a prerequisite from the outset of targeting the entire European market. US corporations are somewhere in between their Japanese and European counterparts. The US makes up an enormous market by itself, making a US-centric, centralized management style most effective. However, the US is a diverse country, originally comprising immigrants from Europe; this is different from the homogenous nature of the Japanese culture and its people. Corporate management structures are based on a flexible labor market, and US-based organizations are highly fluid because of M\&A activities. Thus, management in local entities takes on a variety of structures.

By comparing Panasonic and Philips, two of the world's leading consumer electronics manufacturers, we examine the differences in global management organizations between Japanese and European companies (this discussion is based on Bartlett (2009)). Philips is headquartered in the Netherlands and has a decentralized management structure; marketing of its products are conducted by autonomous sales entities in each country. Philips has made considerable efforts to increase the control from its headquarters and make sales entities in each region follow a consistent, company-wide policy. However, Philips has not been very successful in doing so. On the other hand, Panasonic follows a centralized management system that consolidates the sales entities of each region under a marketing division in Japan. They have set up training and personnel systems for local employees to enable a monolithic operating structure which folds local entities into the Panasonic group.

While multinational corporations have to consider nationality-based differences in the management of local entities, their positioning on the I-R grid changes according to their international business expansion. Figure 2.7 presents trans-national organizational structures that balance global integration and local responsiveness. Global companies from Japan, the US, and Europe are moving in this direction. When Panasonic had a global sales center in Japan and centrally managed overseas branches, each branch manager was required to visit the Osaka headquarters several times a year, and as often as every month (Bartlett 2009). However, the internet has enabled the use of economical video conferencing systems, which has significantly 
reduced the time and money spent on international meetings. The flattening of the world brought about by advances in telecommunication has enabled the management of local entities using a headquarter-led global integration model.

On the other hand, many global companies have overseas revenues that exceed domestic revenues, making local autonomy in operating a business critical. In addition, the primary battlegrounds for global businesses are shifting from developed to developing nations. The circumstances faced by local entities are often different from those faced by headquarters, making it reasonable to give more weight to local responsiveness. Furthermore, giving decision-making authority to local entities and improving local employee morale is critical to utilizing excellent local personnel. Balancing uniform company-wide activities and local entity autonomy requires a seamless organizational operation at a global level by doing away with company borders. For example, Panasonic has standardized internal rankings for management posts in domestic and overseas operations, and promotes local personnel to increase the fluidity of management at the global level. Many companies in the US and Europe have achieved a flat world environment with no apparent borders, operating as trans-national organizations. Japanese companies are working toward the creation of organizational structures that balance headquarters' control and local entity responsiveness.

\subsection{Summary}

In determining management strategies, global companies must focus on the distances between domestic and destination markets, select destinations on the basis of those distances, and strategically consider how to reduce them. This requires new product development that takes products sold in the domestic country and matches them to local needs. Country-specific marketing will also be essential, thus incurring higher costs. In terms of economies of scale, it may be more effective for companies to develop global products to be launched into global markets. The risks associated with global businesses are very different from those in domestic businesses. Political risks, exchange rate fluctuations in local markets, and other factors must be accounted for; risk factors differ depending on a company's focus of localization or global expansion. Thus, when determining global business strategies, companies must make major decisions of whether they wish to focus on localization or global expansion.

Furthermore, from the perspective of improving corporate value via cost reduction, companies have the option of shifting production to developing nations with lower cost. However, while expanding production overseas may result in direct reductions in manufacturing costs, the increase in local management overhead costs may result in no cost reductions unless certain economies of scale are maintained. In addition, companies are exposed to risks distinct to global businesses from the 
production perspective. China has witnessed increasing awareness in terms of labor rights, with labor unions demanding wage hikes. Unions have long been active in India, requiring a serious approach to handle labor disputes. Corporate earnings are greatly impacted when large strikes result in long-term factory closures. In addition, in industries such as the automotive industry, in which the production process comprises a series of close partnerships within a supply chain, the halt of production in one factory impacts the entire supply chain. It is important that companies account for these costs and benefits when determining the validity of shifting a portion of corporate activities overseas. When using the CAGE or AAA frameworks, it becomes critical to extract micro-level factors in the targeted country, however, this may greatly impact profitability.

In addition, these frameworks are created given an external business environment that differs from the domestic country. In corporate management strategy theory, this is akin to the positioning theory that seeks areas of fit to an external business environment. As previously mentioned, global strategies depend on the circumstances prevailing in the countries and regions, and will differ based on the types of products and services provided. Each company must have an understanding of the company's strengths and weaknesses when creating management strategies. Differences in business environments between the domestic country and target markets are not given; rather, companies must observe changes in global environments and trends. Speedy strategies that react to those changes are also important. In the case of the global cell phone market, demand in developing nations increased rapidly, and at one point, mass-produced, low-cost products with limited functionality became popular. In that process, Nokia, Motorola, and other global corporations increased their market shares using models "adapted" for low-income regions. However, explosive popularity of Apple's iPhone shifted the global market trend to highly functional smartphones. Nokia lost its market share and Motorola's cell phone division was sold to Google. However, Samsung was able to quickly ride this trend, and attained significant popularity. Thus, organizational capability that is able to dynamically change its corporate strengths, that is, management resources to external changes in the environment, becomes particularly essential in highly uncertain global businesses.

The final issue is the management of local entities, in which headquarters of Japanese corporations have stronger control compared with their US and European counterparts. This is because of the impact of historical inertia of the standalone product model that provided high quality products at low cost which took over world markets. However, the rise of corporations from developing nations has led to the inability of Japanese corporations to compete on the standalone product model, as has been covered in Chap. 1. The future pursuit of a customer value model in global business will require new product development and the creation of service models, all while precisely grasping the trends in target markets. As observed in the case of Panasonic, Japanese companies are searching for a balance in trans-national 
management between global integration and local responsiveness. As they do so, the debate on the integration of a company's global entities and activities across differing countries and regions is important. We return to this topic in Chap. 13, which contains the summary of this book.

Open Access This chapter is distributed under the terms of the Creative Commons Attribution Noncommercial License, which permits any noncommercial use, distribution, and reproduction in any medium, provided the original author(s) and source are credited.

\section{References}

Barney, J. B. (1986). Strategic factor markets. Management Science, 32, 1231-1241.

Barney, J. B. (1991). Firm, resources and sustained competitive advantage. Journal of Management, $17,99-120$.

Bartlett, C. (2009). Philips versus Matsushita: The competitive battle continues. Boston: Harvard Business School Case.

Bartlett, C., \& Ghoshal, S. (1989). Managing across borders: The transnational solution. Boston: Harvard Business School Press.

Friedman, T. L. (2005). The world is flat: A brief history of the twenty-first century. New York: Farrar Straus \& Giroux.

Ghemawat, P. (2007). Redefining global strategy. Boston: Harvard Business School Press.

Numagami, T. (2009, September). Keiei Senryaku no Shikou. Tokyo: Nihon Keizai Shinbunsha.

Porter, M. E. (1980). Competitive strategy: Techniques for analyzing industries and competitors. New York: Free Press.

Prahalad, C. K., \& Doz, Y. L. (1987). The multinational mission: Balancing local demands and global vision. New York: The Free Press.

Teece, D. J., Pisano, G., \& Shuen, A. (1997). Dynamic capabilities and strategic management. Strategic Management Journal, 18, 509-533. 